\title{
Helen Salisbury: When is a consultation not a consultation?
}

\author{
Helen Salisbury GP \\ Oxford
}

\begin{abstract}
"Why has this patient come to see me?" This is a question every doctor asks many times a day. Often the answer is obvious, especially when the patient has a new symptom and wants to know what it signifies and how to make it better. Sometimes the reason is more complicated: perhaps the consultation was prompted by colleagues at work complaining about a persistent cough, or by a partner issuing an ultimatum on doing something about the patient's weight, mood, or alcohol consumption.
\end{abstract}

Knowing why the patient has come to your surgery can be a clue as to how seriously your advice is likely to be taken. Many GPs will remember interactions with reluctant but dutiful patients, their minimal engagement encouraging you to deploy every communication and rapport building skill in your repertoire, often with limited success. We have a strong sense at the end of these consultations that our advice about exercise will not be acted on and that the contact details for psychological therapy will be binned. Having complied with the wishes of whoever sent them by coming to see the doctor, patients may believe that they've "ticked that box" and will continue along their previous path.

I got thinking about such unsatisfactory consultations when reading the draft specification for the new primary care network direct enhanced service, which NHS England put out for consultation just before Christmas. ${ }^{12}$ The specification sets out the proposed new contract for general practices participating in primary care networks.

If public organisations that regulate or provide services want to make changes to what they're doing this usually means consulting with the public or the people affected. The question is: do they have any intention of altering their proposals in the light of responses received? Or are they just ticking a box, consulting for the purpose of window dressing, to rubberstamp decisions that have already been taken?

The timescale for the above consultation is tight. The survey is online from 23 December 2019 to 15 January 2020, and the changes are to be implemented by April 2020. It therefore seems unlikely that responses from the profession were actually desired. Which is a pity, as the whole proposal is woefully misguided, apparently built on assumptions by NHS England and NHS Improvement about staff and capacity in primary care networks that don't match the reality (at least, not on my patch). We'll be judged on the proportion of patients referred to a social prescriber or who have had a "patient activation measurement assessment": the intention to micromanage general practice signalled in this document is worrying, and a future of patient consultations dominated by yet more process and coding, rather than meaningful interactions, is a real threat. Primary care networks were originally sold to us as ground-up collaborations to meet specific local needs. This proposal is the exact opposite, a top-down imposition that is uniform and prescriptive and totally fails to tackle variation and, crucially, deprivation.

I may be sure that the patient visiting me just to keep someone else happy has little real intention of giving up smoking, but I'll still do my utmost to engage, to sow the seeds of change. In the same spirit, I've filled in the survey on the network contract.

If nothing does change, practices have the option of walking away from this contract—and some local medical committees are already advising this course of action.

Competing interests: See www.bmj.com/about-bmj/freelance-contributors. Provenance and peer review: Commissioned; not externally peer reviewed.

1 NHS England. Primary care networks service specifications. Opened 23 Dec 2019, closes 15 Jan 2020. https://www.engage.england.nhs.uk/survey/primary-care-networks-servicespecifications/.

2 lacobucci G. New primary care network contract won't work, GPs warn. $B M J$ 2020;368:m39. 10.1136/bmj.m39 31911450

Published by the BMJ Publishing Group Limited. For permission to use (where not already granted under a licence) please go to http://group.bmj.com/group/rights-licensing/ permissions 